\title{
Changing Consciousness, Values, and Culture in Advanced Industrial Societies
}

\section{Herman Lebovics}

SUNY at Stony Brook

The well-organized and well-conceived Fifth International Conference of Europeanists held in Washington, D.C. over the weekend of October 18, 1985, of fered a set of wide-ranging panels which in various ways addressed themselves to two connected themes: the search for a third way in Western Europe between a discredited communist orthodoxy and a faltering social democracy, and, finding ways to deepen democracy from social relations to the shop floor to the conduct of national life in the societies of Europe. Panels on class formation, consciousness, and the state, new social movements, changing workplace culture, the social workings of Weimar Social Democracy, the sexual division of labor in production, and a concluding panel entitled "Beyond Social Democracy," addressed aspects of these themes.

In the discussion of class formation, working-class consciousness, and the French state Ira Katznelson (New School for Social Research) reported on a forthcoming collection of essays by various authors on working-class formation which started from the premise that there is no single model of working-class emergence, nor is there any basis for accepting claims of national exceptionalisms. In a creative piece of cliometric work, Michael Hanagan (Columbia) demonstrated how the changing economic opportunities in agriculture for migrants from farms to industrial centers in the Stephanois from the 1850s to the 1880 s held back or reinforced working-class consciousness. Only when the opportunity to return home and buy a farm had become impossible, could the sense of working-class identification grow. My own paper at this session focused on the impact of rising worker consciousness in speeding both the unification and rise to political dominance of the socioeconomic elites of the new Third Republic. Anne Meyering (Michigan State) described the shift in the leadership of local political influence from priests to industrialists in Montluçon under Napoleon III. Louise Tilly (New School), the discussant, emphasized the need to be sensitive to regional and local variations especially for nineteenth-century France.

A discussion of contemporary social movements examined the hypothesis that the new politics will be social and cultural in content rather than oriented around economic values. Margit Mayer (Frankfurt/M) comparing German and United States grassroots movements found that above all they differed politically. The Greens challenge the legitimacy of the political order, for exam- 
ple, while United States grass-roots groups focus largely on gaining more resources for their constituencies. But in both cases, she concluded, the chief stresses on the movements lay in the governments' attempt to fragment or restructure them to match their interests to those of the state. The result is internal tensions in the groups between the wish to make the impact desired by the members and acceptance as a legitimate organization by policymakers. Dieter Rucht (Munich) described the new movements in Europe (especially in the Federal Republic) as originating not in deprivation but rather in an "expanded concept of opportunity structure." He characterized them as linking demands for participatory democracy with anti-modernism. Herbert Kitschelt speaking of the West German and Belgian ecological parties suggested that if they continued in their successes we may have to revise, or even abandon, the Iron Law of Oligarchy in the study of the development of those sorts of political parties. What was missing in these papers as Andrei S. Markovits (Boston) pointed out, was attention to the current macro-economic crisis associated with the movements. Nor were the issues of class or the larger economic context clarified.

The discussion of changing workers and changing workplace heard JeanPierre Durand (Rouen) on the computerization of the French auto industry. He noted management's replacement of its usual policy of fragmentation and deskilling of the work force in the industry and by a new emphasis on fostering highly skilled personnel involved and committed to their tasks via Direct Expression Groups and Quality Circles. This bypasses unions and thereby causes difficulties with the workers, but middle management also perceives this strategy as threatening for it sees its power eroding at the workplace. Michael Rose (Bath) mocked Prime Minister Thatcher's lamentations of the decline of the work ethic, labelling it as a vague notion with little basis even in Victorian worklife. Specialists in French history suggested that decline in the work ethic was not a concern in France and that this was perhaps an Anglo-American managerial fetish. George Ross (Brandeis, Center for European Studies, Harvard) commented that national variation in managerial styles had to be considered; they might be even more important than the labor process. Rose suggested in conclusion that what might be being criticized in England was the phenomenon-admittedly of the white-collar world primarily-of men's growing commitment to obligations of the family and couple which requires redefinition of men's relation to their jobs. Several members of the audience pointed out that if this was occurring, it was because of women's greater dedication to work and career, so that, if we accept the Thatcher problématique, we would have to stipulate that the work ethic is on the whole growing.

Geoff Eley (Michigan) chaired an excellent panel on German Social Democracy during Weimar. Basing his remarks on his new work on the SPD, David Abraham argued that the SPD rested its hopes for democratization in the 1920s and early 1930s on electoral institutions and its hopes for workers' 
progress on cumulative economic gains. But the economic and political collapse of Weimar destroyed that strategy and the party. Atina Grossman (Mount Holyoke) discussed the SPD-sponsored (and world's first) birth-control clinics in Berlin and the ensuing conflict between public institutions and health workers and private medical practitioners as a part of the general crisis in German social policy over the role the state could play in empowering the lives of its citizens. David Crew (Texas) reported on some of his work which attempts to sort out the uncertain and twisting path of SPD social policy towards the family. In her incisive commentary Jane Caplan (Bryn Mawr) crystallized a number of the issues running through the papers by asking that we pay attention to what she called "a socialist assessment of needs," and especially to the dangers that they might be prescribed from above. Thus, what was the SPD's notion of the family? Probably something very conventional and limited. Why did this party, even when in the government majority, focus in its social policies primarily on protection rather than liberation? Further, with an imaginary, that is, ideologically constructed, idea of the working class the SPD excluded deviate groups from being reached; as in the case of the family, it defined the working class too narrowly for its own good and for the future good. Rather than looking for the right formula by which people might be aided or protected, the SPD might have empowered Germans to self-emancipation.

Three local studies examined the division of labor by gender in a panel chaired by Louise Tilly. Tessie Liu (Michigan) traced how in nineteenth-century southern Anjou the switch-over from grain-farming with female by-employment in linen spinning to cattle raising for the market reduced the money value of women's labor to the household and deprived them of the independent income gained from working the linen. Her study of witchcraft beliefs in the region suggests that the male heads of households were seen as the possessors of farm, chattels, and family. Jean Quataert (Houston) discovered that in turn-of-the-century Saxony the discontinuous employment of married women in the textile factories and their household labors proletarianized women in different ways and at a different pace than the men. The two sexes also lived in different political worlds, although the women had more public influence than could be deduced from knowledge of their formal rights. Finally, in her study of the Nottingham hosiery industry between 1850 and 1900 Sonya Rose (Colby) determined that jobs in the new factories were in some cases defined by employers as "male" or "female" on the basis of gender ideology rather than the logic of capitalist production.

Described by the Chair Leo Panitch (York) as a "book-end session," the last relevant panel in a sense capped the earlier papers and left us with a final focus for thought. Although the topic was "Beyond Social Democracy," none of the participants voiced any clear idea of what lay beyond it. Carl Boggs (Carleton) treated the failure of the early hopes for a Mediterranean Euro- 
socialism of the early 1980s and its retreat and retrenchment by 1983-84 to varieties of state-managed capitalism. Mark Kesselman (Columbia) agreed with Boggs on the "exhaustion of socialist visions on the Left in France." But despite the durability of a number of its reforms, he argued, the record of its failures in governance will be damaging for French socialism, as will be the socialists' insistence that their compromises, omissions, and retreats were not such but the correct actions of a realistic socialist policy. Kenneth Wald (Florida), also expressed pessimism for British Labour's chances of political success using electoral strategies. Carl Lankowski (SUNY/Albany) raised the possibility that socialism might yet come to Germany, and perhaps other European nations, via the new ecological, environmental, antinuclear, and progressive-Protestant movements. David Abraham (New School) in his commentary was still unwilling to write off the potential for resurrection of political movements like social democracy, while James Petras (SUNY/Binghamton) found it ironic that intellectuals were giving up the idea of "class" at a moment of intense classist oppression. George Ross from the floor pointed to the role of the Western Communist parties as an important force in pushing the socialists to the left and keeping them there. With the collapse of these CPs he predicted that the socialist parties would become mass liberal parties something like the American Democratic party.

With no one able to discern future successes, at least in the short run, for either worker parties or trade union struggles, analyses of the new movements of Europe captured much attention at the conference. However, an assessment of the social bases and economic contexts of these movements was lacking, as was an in-depth consideration of what we must see as a full-blown crisis of contemporary European workers' organizations and opportunities. 